\title{
Establishment and inaugural meeting of the Australian and New Zealand Purine Club
}

\author{
Geoffrey Burnstock ${ }^{1} \cdot$ Jennie M. E. Cederholm ${ }^{2} \cdot$ Ronald Sluyter $^{3,4} \cdot$ Srdjan M. Vlajkovic $^{5}$
}

Received: 3 June 2019 / Accepted: 13 June 2019 / Published online: 17 July 2019

(C) Springer Nature B.V. 2019

Cellular effects of extracellular purines were first reported in 1929 [1], which eventually gave rise to the concept of purinergic signalling, first proposed by Geoffrey Burnstock in 1972 [2]. The classification of P1 and P2 receptors followed later that decade [3], with the eventual sub-classification of P2 receptors into P2X and P2Y receptors in 1985 [4]. Since then, the field of purinergic signalling has grown to include ectonucleotidases [5], and ATP release channels and pathways [6]. This growth has coincided in part with the establishment of Purine Clubs with the first formalized in Italy in 1991 with subsequent clubs forming a decade later in Germany (2000), Japan (2003), Brazil (2009), the UK (2009) and North America (2009) [7]. The Chinese Purine Club was formed in 2018 and its inaugural meeting held in April 2019, Chengdu, China. The major activity of the various Purine Clubs has been their respective scientific meetings, with some involving combined club meetings such as the First Italian-German Club Meeting, Chieti, Italy (2005); the First United Kingdom-Italian Purine Club Meeting, Bristol, UK (2016); and First European Club Meeting, Santiago de Compostela, Spain (2019) [8].

Ronald Sluyter

rsluyter@uow.edu.au

1 Department of Pharmacology and Therapeutics, University of Melbourne, Parkville, Victoria 3010, Australia

2 Translational Neuroscience Facility and Department of Physiology, School of Medical Sciences, University of New South Wales, Kensington, NSW 2052, Australia

3 Molecular Horizons and School of Chemistry and Molecular Bioscience, University of Wollongong, Wollongong, NSW 2522, Australia

4 Illawarra Health and Medical Research Institute, Wollongong, NSW 2522, Australia

5 Department of Physiology and Eisdell Moore Centre, Faculty of Medical and Health Sciences, University of Auckland, Auckland 1142, New Zealand
In Spring 2018, the Australian and New Zealand Purine Club was initiated and formed by Geoffrey Burnstock (President), with Jennie Cederholm and Ronald Sluyter (CoPresidents), and Srdjan Vlajkovic (New Zealand Representative) comprising the founding Executive Committee. The purpose of the Australian and New Zealand Purine Club is to provide a platform for Australian and New Zealand scientists to disseminate their purinergic signalling research; provide opportunities to build existing and develop new collaborations and networks; provide leadership and other career development opportunities for early-/mid-career researchers and research students; and to promote Australian and New Zealand purinergic signalling research internationally.

In May 2019, the Australian and New Zealand Purine Club held its inaugural meeting in Melbourne, Australia, attracting some 40 delegates. The meeting was organised by the Executive Committee and included four sessions: Concepts and Pharmacology; Sensory Systems; Physiology and Pathophysiology; and Inflammation and Immunity. The sessions comprised 19 oral communications in total including an opening address from Geoffrey Burnstock (University of Melbourne) on the discovery and development of purinergic signalling. The meeting included three invited lectures. Gary Housley (University of New South Wales) presented an overview of the role of $\mathrm{P} 2 \mathrm{X} 2$ receptors in hearing and hearing loss; James Wiley (Florey Institute of Neuroscience and Mental Health) outlined new roles of the P2X7 receptor including phagocytosis; and Lu Liu (University of New South Wales) described the role of this receptor in bladder inflammation. Extended lectures were also delivered by Julian Paton (University of Auckland) on the role of $\mathrm{P} 2 \mathrm{X} 2 / \mathrm{P} 2 \mathrm{X} 3$ receptors in carotid bodies and cardiorespiratory diseases, and Sabatino Ventura (Monash University) on the potential of P2X1 receptors as a target in non-hormonal male contraception. Kirstan Vessey (University of Melbourne) and Anna Wang (University of Melbourne) were awarded best oral presentation by an early-career researcher and a research student, respectively, for their individual presentations on purinergic receptors in 
the retina. The four sessions showcased some of the major themes of Australian and New Zealand purinergic signalling research. For many of the junior participants, the meeting afforded them the first opportunity to hear from and meet with national and international leaders in the field of purinergic signalling, and to interact with purinergic researchers outside their own institutes and traditional disciplines. Abstracts from the meeting are published in this journal.

Following on from the success of the inaugural meeting of the Australian and New Zealand Purine Club, future meetings are planned. Furthermore, there remains a strong and vibrant interest by many groups and institutes in developing purinergic research across the region and translating research outcomes to health and disease both locally and globally.

\section{Compliance with ethical standards}

Conflicts of interest Geoffrey Burnstock declares that he has no conflict of interest.

Jennie M. E. Cederholm declares that she has no conflict of interest. Ronald Sluyter declares that he has no conflict of interest.

Srdjan M. Vlajkovic declares that he has no conflict of interest.

Ethical approval This article does not contain any studies with human participants or animals performed by any of the authors.

\section{References}

1. Drury AN, Szent-Gyorgyi A (1929) The physiological activity of adenine compounds with especial reference to their action upon the mammalian heart. J Physiol 68:213-237. https:/doi.org/10.1113/ jphysiol.1929.sp002608

2. Burnstock G (1972) Purinergic nerves. Pharmacol Rev 24:509-581

3. Burnstock G (1978) A basis for distinguishing two types of purinergic receptor. In: Straub RW, Bolis L (eds) Cell membrane receptors for drugs and hormones: a multidisciplinary approach. Raven Press, New York, pp 107-118

4. Burnstock G, Kennedy C (1985) Is there a basis for distinguishing two types of P2-purinoceptor? Gen Pharmacol 16:433-440. https:// doi.org/10.1016/0306-3623(85)90001-1

5. Zimmermann H, Zebisch M, Strater N (2012) Cellular function and molecular structure of ecto-nucleotidases. Purinergic Signal 8:437502. https://doi.org/10.1007/s11302-012-9309-4

6. Taruno A (2018) ATP release channels. Int J Mol Sci 19:808. https:// doi.org/10.3390/ijms19030808

7. Burnstock G (2010) The history of National Purine Clubs and the International Purine Club. Purinergic Signal 6:283-284. https://doi. org/10.1007/s11302-009-9177-8

8. Pedata F (2017) From the 7th Joint Italian-German Purine Club Meeting to European Purine Club Meetings. Purinergic Signal 13: 683-685. https://doi.org/10.1007/s11302-017-9580-5

Publisher's note Springer Nature remains neutral with regard to jurisdictional claims in published maps and institutional affiliations. 